\title{
A Holy Relic of War: The Soviet Victory Banner as Artefact
}

\section{Jeremy Hicks}

Since 1965, the centrepiece of 9 May Victory Day celebrations in Moscow has been a parade on Red Square in which the Victory Banner raised over the Reichstag on 30 April 1945 is ceremonially displayed by a guard of honour before the watching public. The banner is a red Soviet flag bearing the hammer and sickle emblem, with the name of the unit that raised it added in white ${ }^{1}$. Newsreel and still photographic images of the raising of the Victory Banner over the Reichstag became a central symbol in the 1960s birth of what has been called a Soviet war 'cult' (Tumarkin 1994, 137). More recently, the actual banner and - since its official adoption as an official state symbol in 2007 - replicas of it have played an increasingly important role in articulating and disseminating the Soviet and post-Soviet Russian view of victory in the Second World War, the Soviet dimension of which has long been referred to as the Great Patriotic War.

This chapter is an attempt to understand how this flag came to acquire such symbolic resonance, and to trace how its place within the practices of Second World War commemoration that have evolved since May 1945. The introductory section adumbrates a theoretical approach premised on the notion that national understanding of the past is constructed in part through the selection and mediation of symbols. I then trace the fate of the Victory Banner from its initial journey to Moscow in May 1945, examining its installation in, what is now known as the Central Museum of the Armed Forces and the ways in which the changing approaches to displaying it in the 
years since have variously constructed this symbol's meaning amidst changing societal attitudes to the war. I then explore the use of the banner in parades, both formal and informal, since its revival in the 1960s; the debates around the Victory Banner's second revival in the 1990s and early 2000s, when it became a central symbol of the post-Soviet Russian state; and its recent appropriation as a political symbol across the post-Soviet space in political demonstrations. While sketching out the broad historical and political context, I will also analyse in detail how the Banner's incorporation in specific museum sites, parades, performances and reenactments has reinflected and reshaped both its meaning and the broader memory of the war.

\section{Understanding 'Invented Traditions'}

In her influential study of what she called the 'cult' of the war in the Soviet Union, Nina Tumarkin discusses the Victory Banner as a holy relic:

By 1975, the war cult had so deepened and its accompanying language had become so sentimental that the Victory Banner had gained the epithet 'holy of holies' and had been turned into its single most exalted relic, an embodiment of the collective virtue implied in the official remembrance of the victory (Tumarkin 1994, 137).

For Turmarkin, this was evidently ridiculous and she quoted a sceptical 1970s teenager's lack of interest in the Victory Banner, implicitly dismissing any claim as to its auratic power as nothing but hollow rhetoric. This dismissive attitude seems erroneous, and it is not unrelated to the book's profoundly mistaken assumption that 
the practice of commemoration of the Great Patriotic War was in terminal decline and would disappear in post-Soviet Russia.

One factor informing Tumarkin's study, and her condescension towards the sacred status conferred by the Soviets upon the symbol of the Victory Banner, was an assumption that Soviet inconsistencies and silences about the war would mean a postSoviet move from collective to individual grieving and the end of the 'war cult' (Tumarkin 1994, 226). ${ }^{2}$ This approach stems from a tradition in historical scholarship that sees its task as consisting in the distinguishing between mythical elements, including what we have come to term 'memory', and the factual elements of history, which are not only primary but ultimately pivotal in shaping societal understanding. Implicit in this approach, as with Eric Hobsbawm's attempts to show how 'invented traditions' associated, for example, with the English royal family were actually symbolic practices invented fairly recently with the aim of constructing a spurious continuity, was wishful thinking masquerading as scholarly method: an assumption that exposing the constructed nature of memory would lead to it becoming less influential (Hobsbawm 1983, 1). Working within a different tradition, the paradigm of memory studies, Aleida Assmann, has criticised this method:

By showing that some traditions are a fake, such categories as 'true' and 'authentic' were affirmed and reinstated ex negativo. It was the trust of enlightenment shared by these historians writing on the presuppositions of Marxist and modernization theory that by the very act of exposure, by merely pointing to the inventedness, manufacturedness, and hence to the 'falseness' of the tradition, its spell would be broken and automatically dissolved (Assmann 2008, 66). 
Assmann argues that this is a misunderstanding of the way in which traditions function in the context of collective memory:

Memory constructs that inform commemorative practices and traditions are ... not necessarily false because they are constructed — of course they are! The questions to be asked should not only focus on empirical evidence and the substance of the narrative or tradition alone but ought to take the wider context into account: Why and how do memory constructs work? Why do they succeed to mobilize? Why do they find or fail to raise mass support and resonance? As they are necessarily selective, the question is: By which norms and bias are they chosen? What is included and what is excluded from the constructions of collective memory? And what are the political consequences of such choices in the present and for future? (Assmann 2008, 67)

It is this perspective, which sees the Victory Banner as a 'mobilizing symbol' within an 'affectively charged narrative', that informs the present study: it as an attempt to understand how the symbol functions, how it acquired the power it now wields, and what effects this particular 'memory construct' has in the societies where it has become prominent.

Assmann sees this kind of collective memory as 'social, political, national, and cultural memory' and argues that it works together through a range of forms, which are vehicles for a range of representations. These include:

- Emplotment of events in an affectively charged and mobilizing narrative;

- visual and verbal signs that serve as aids of memory;

- institutions of learning and the dissemination of mass media; 
- sites and monuments that present palpable relics;

- commemoration rites that periodically reactivate the memory and enhance collective participation (Assmann 2008, 55).

The distinctive and privileged nature of the Victory Banner as a Soviet and Russian symbol of the Second World War is evident from a consideration of its relation to these categories. Effectively, one might say that it relates to all of them. Evidently it is a symbol aiding memory, but since it represents the final, most triumphant, moment of the Soviet victory, it also serves to articulate an 'affectively charged' narrative. As a museum object, it is a 'palpable relic', housed in a museum with an ostensive educational function. And, finally, it has played and continues to play a role in 'commemoration rites' with an increasingly wide dimension of 'collective participation'. First and foremost, however, the Victory Banner is an object that functions as an artefact and a relic.

\section{The Victory Banner as Artefact: The Power of Objects}

There is an extensive literature devoted to the discussion of museum objects, the overwhelming tendency of which is to see them as central to museums' claims to authority and truth: 'objects play a crucial role as material evidence supporting a particular version of the world and events in it' (Stead 2007, 38). However, as Naomi Stead characterises it, there has been a historic tension between those who see the museum object as inherently meaningful, bearing a trace of its original context and use, on the one hand, and those, on the other, who see the objects as acquiring meaning when placed in a 'network of interpretation' (Stead 2007, 38). In this instance, the Victory Banner might be seen as an inherently meaningful symbol of 
victory, or rather an indexical proof of it, because it is the actual flag raised over the Reichstag to signify victory. However, the situation is in fact far less straightforward, for several reasons. First, the actual Victory Banner was neither the first nor the only flag raised over the Reichstag during and immediately following its storming and capture on 30 April-2 May 1945: each of the Red Army units attacking the Reichstag from different directions, raised a Red flag on the building, from various points such as a window, a balcony, a column, an equestrian statue on the roof or the building's cupola. The official Victory Banner appears only to have been raised later (Pospelov et al. 1963, 282-85). Second, the capture of the Reichstag was not the most strategically or politically significant moment in the battle of Berlin, or the fall of the Nazi regime, given that it was not a centre or symbol of Nazi power and the German act of capitulation was signed days after its capture. Third, the singularity of the Victory Banner as a museum object is a paradox, since it is essentially just a red flag bearing the hammer and sickle emblem of the Soviet Union: its ubiquitous state flag. Fourth, as an index of the event it is rivalled by photographic and filmic images purporting to record the capture of the Reichstag. All of which suggests that the fact that this particular flag has come to serve as a unique signifier of victory is the product of a discourse, a conventionalised narrative, which is the subject of our investigation.

This discourse has conferred upon the Victory Banner a perceived special power, an originality and authority that might be conceptualised in terms of Walter Benjamin's notion of 'aura', originally coined to describe works of art, but also adapted to apply to museum objects (Walsh 1992, 35). Benjamin saw aura as relating to the cultic and ritual value of the object (Benjamin 1992, 237) and it is this fetishistic (Belting 1998, 
19), or implicitly sacred, quality possessed by the museum object that is particularly relevant to an understanding of the ways in which the Victory Banner has come to be seen and used in Russia and the former Soviet Union since 1945. Also relevant here is Emile Durkheim's division of objects into the sacred and profane as a feature of religious belief, arguing what makes an object sacred is not an intrinsic property, but rather attitudes and social rituals attached to it, and the setting of it apart from the profane sphere (Durkheim 1995, 37). Rituals of consecration are key to transmitting the sacred qualities of an object, due to the 'extraordinary contagiousness' of the sacred (Durkheim 1995, 322). As we shall see this also relates to the way in which the Victory Banner was presented as sacred and contrasted with profane objects through its use in Victory Parades and the narrative constructed around it in its museum home.

\section{The Victory Banner as Museum Object: The Evolution of a Relic}

The Victory Banner did not actually take part in the 24 June 1945 Victory Parade on Red Square, after the frontline troops who had initially raised the flag and were due to carry it performed poorly at the dress rehearsal the previous day (Neustroev 1990, 144). Instead, Marshal Georgii Zhukov, who was to be the central figure in the

parade, sent the Banner to what was then called the Central Museum of the Red Army (now the Central Museum of the Armed Forces). Nevertheless, despite the Victory Banner's absence, other banners played a key role. The voice-over for the commemorative documentary film, entitled Victory Parade (Parad pobedy, Vasilii Beliaev, Irina Venzher and Iakov Posel'skii, 1945) identified the representatives of the various 'fronts' as they marched past the mausoleum podium, and as the $1^{\text {st }}$ Belorussian front filed past, the commentary stated that they were carrying thirty-six 
battle banners: 'They took the Reichstag and raised the Victory Banner over Berlin.'

Banners were once again to the fore in the original parade's most dramatic moment, when to the stirring rhythm of eighty drummers, 200 captured Nazi banners were cast down before Lenin's mausoleum. This performance reworked the contest of symbols, the old versus new, which had been key to pre-war Soviet parades, only now it was not the church or internal opponents but the Nazis who were associated with the profane (Rolf 2013, 41). Their vanquished symbols were contrasted with Lenin's mausoleum and the leaders, including Stalin, standing upon it. Later, when placed in a museum, the Victory Banner would similarly be contrasted with the Nazi banners, taking on a sacred status from its differential opposition to them.

In the first year after the war the Central Museum of the Red Army was almost entirely devoted to the Great Patriotic War and contained an enormous number of artefacts, but the Victory Banner was not yet presented as an exceptional object. Rather it was just one among many physical artefacts of the war including a sniper's rifle that killed more than 1,000 Germans, mounted on red velvet, and the effects of fallen heroes, such as Zoia Kosmodem'ianskaia., the 18 year-old schoolgirl, dropped behind enemy lines during the Battle of Moscow, captured, tortured and killed by the Nazis, who was the subject of a number of propaganda narratives across many media. Not only was the Victory Banner initially one among many other artefacts of the war, it was also overshadowed by the museum's emphasis upon Stalin as the central figure in wartime victory. As the official museum guidebook put it:

In the Museum's rooms the visitor sees orders issued by Supreme Commander Marshall Stalin during the Great Patriotic War, letters from Red Army 
soldiers, officers and workers of our Motherland to comrade Stalin and other documents testifying to the uniting of the Soviet people around the Party of Lenin-Stalin and the government to resist the enemy. Battle plans, genuine relief maps and documents show the realisation of the genius of Stalin's strategic plans for the defeat of the German-Fascist invaders (Anon 1946, 12).

The description of how the Victory Banner was displayed also underlined the overriding importance of this Stalin-centric narrative:

The Museum display concludes with the Hall of Banners. Here one can find the military banners of the Red Army units who have distinguished themselves in battles for the Motherland. Soviet medals received by the divisions and regiments are attached to the banners, with their medal ribbons. On a high pedestal, lit up by projectors, burns the red flame of the Victory Banner raised on the German Reichstag on 30 April 1945. In the centre of the Hall, is a bust of the Great Leader, the commander of genius, comrade Stalin, under whose leadership the Soviet people and their armed forces won historical victories in the Great Patriotic War (Anon 1946, 3-4).

Alongside the bust of Stalin, the Victory Banner is already the culminating point of the museum, and it is presented dramatically, in a glass case, lit with projectors, so as to underline its importance and auratic power. Yet, the Hall of Banners does not only contain flags relating to the Second World War, and to the Victory parade, but also contains flags relating to the defence of the Soviet state in previous conflicts such as the Civil War. The Victory Banner did yet play the central political role it would later assume. 
By the final year of Stalin's life, the museum had been remodelled so that ten of its fifteen rooms were devoted to the Great Patriotic War, with three on the Civil War, one on the inter-war period and one on the post war (Arsenin 1953, 115-18). There were now sculpted portraits of the soldiers credited with raising the flag, Mikhail Egorov and Meliton Kantariia, a model of the burning Reichstag, photographs and other materials about the last days of the war all alongside the Victory Banner, now displayed with other materials representing the battle of Berlin rather than in the 'Hall of Banners.' For the first time the guidebook stressed its sacred character: 'Here is the holy relic of the Great Patriotic War — the modest red flag with the names of the unit that captured the Reichstag — the Victory Banner' (Arsenin 1953: 80).

Even though the Victory Banner itself was no longer in the 'Hall of Banners', the references to Victory and the 19459 May Victory Day and also for the first time, of the 24 June 1945 parade, were now very prominent in this room. Moreover, while even before Stalin's death his bust had been removed from the Hall of Banners, evidently visitors were still supposed to think of him when visiting it. as the guidebook makes clear:

Before leaving the Museum, visitors proceed to the Hall of Banners, the contents of which seem to sum up the whole collection. In the centre of the Hall hangs the painting 'Victory Salute.' On the 9 May 1945 Muscovites celebrate Victory Day. And all their thoughts and cogitations are for the architect of the greatest military triumph of our Motherland, comrade Stalin (Arsenin 1953, 86).

In this organisation of the room, the banners of the conquered German armies lay on the ground before the triumphant Soviet ones as they had in the June 1945 Victory 
Parade, yet they mingled with other symbols of triumph including flags of Civil War White guards and interventionists as well as those of the Japanese in the Second World War. Thus, despite acquiring stronger associations with the sacred, implicitly underscored by the contrast to profane Nazi banners, the Victory Banner's singularity and the unique importance of the Second World War were not yet so apparent. Rather it was integrated into and subordinated within a system of Soviet symbols in which Stalin was still key and which stressed a longer revolutionary history.

Following Stalin's death in 1953, the Victory Banner, still in its glass case on a tall pedestal, remained at the centre of a room devoted to the storming of Berlin. As explained by the guidebook, this was now the penultimate room of the museum, followed only by a room that spelled out the importance of the Soviet Army (as the Red Army had been renamed in 1946) for the maintenance of peace in the contemporary world (Anon 1955, 21). As the now dead Stalin receded from view within official Soviet symbolism, the Victory Banner's indexical significance connoting the pinnacle and culminating point of Soviet martial achievement meant that it was becoming more prominent. It now had to perform some of the symbolic function once carried out by the image of Stalin, as a kind of widely recognised shorthand for the Communist cause and the Soviet state.

While the 1963 fifth volume of the official six-volume history of The Great Patriotic War had encountered such difficulties in getting to the bottom of the eyewitness accounts of who actually put up the Victory Banner, and instead stressed the multiplicity of flags raised over the Reichstag, and the fact that the official Victory Banner was raised later than the others (Pospelov et al. 1963, 282-85), such 
potentially iconoclastic discourses were quickly drowned out by the triumphalist fanfare of commemoration unleashed following the deposing of Nikita Khrushchev and Leonid Brezhnev's October 1964 ascent to the post of First Secretary of the CPSU. Thus the hastily organised 9 May 1965 Victory Parade, which entailed the last minute cancellation of the tradition 1 May military parade, placed the Victory Banner at its centre, making its entry onto Red Square, held aloft by Egorov and Kantariia, the signal for the start of the parade. While it is unclear who took the decision to include the flag in the reinvented parade, the mobilising of its symbolic significance was illustrative of the wider approach to the war in the Brezhnev period. The same year, the now renamed Central Museum of the Armed Forces of the USSR, moved to a new building, opened on the eve of Victory Day, where the Victory Banner was prominently displayed in its own special Victory Hall, where it was elevated and sealed in glass above a photograph of the June 1945 Victory Parade showing the lowered profane Nazi banners (Pisareva and Poplyko 1969, np). True, symbolism around the war was still in flux in the 1960s, and one guide book to the Museum published in 1965 emphasising photographs of exhibits did not include an image of the Victory Banner (Anon 1965). Yet the general trend was clear as the Banner assumed ever greater auratic power.

The fact that the Victory Banner was not a part of the 1945 Victory Parade, as opposed to the post-1965 Victory Day parades, was not made clear in the museum; indeed, the displays seemed to imply that it was present. As the Banner came to serve as the ultimate symbol of victory after 1965 , so a number of accounts erroneously reinserted it into descriptions of the 1945 parade (Svoichakov 1973, 222). One eyewitness account called the parade unforgettable, but on the same page referred to 
the Victory Banner as being there, and as having been transferred to the museum after the parade (Drozdovskii et al. 2000, 50). Yet another eyewitness was quoted describing how the Banner appeared on Red Square that day:

On the day of the parade the Victory Banner was fixed to a specially adapted open-topped automobile above which a large globe was suspended. The Victory Banner was fixed to it on a spot marked with the word 'Berlin.' I shall never forget that day in Moscow (Tiurin 2000, 32).

The proliferation of such false memories underlines the incredible combined mythcreating power of the Victory Banner itself, the museum and the post-1965 Victory Day parades. The symbolic, sacralised, power of the Victory Banner continued to grow throughout this late Soviet period, so much so that by 1985 , not only did the Victory Banner occupy its own special Victory Hall, but this was so much the most important part of the museum that one could buy a guidebook devoted it alone (Anon 1985). Before the collapse of the Soviet Union, work was already under way on a project to build a grandiose museum and memorial complex to victory in the Great Patriotic War at the Hill of Prostrations in Moscow (Schleifman 2001). The Victory Banner was scheduled to be moved to the new museum, and housed in a new Hall of Glory, while a dedicated memorial to it was also to be constructed (Synthart 2011). The project was frozen in 1987, and only completed in 1995, though then without the Victory Banner itself or the monumental sculpture to it. This is a result of the timing of its completion at the height of the Yeltsin years, when, as we shall see, there was a concerted attempt to rethink memory of the war so as to cleanse it of all Communist symbolism such as the Victory Banner. 
So it is that, although the basic format of the room devoted to the Victory Banner, the storming of Berlin and the Moscow Victory Parade of 24 June 1945 have apparently continued unchanged to this day, even if, since 1965, the actual flag has been kept in a sealed capsule so as to arrest its decay (Anon 2015, 2011), this apparent continuity obscures the remarkable fact that the Victory Banner only grew to acquire its special, or independent, auratic power in the post-Stalin years, when it came to take the place of the charismatic leader cult. The overall continuity of the flag's place in the museum and use in the Red Square Victory Day parade also masks the more profound contradiction that, what is in essence the state flag of the Soviet Union has survived that state's disappearance to become a state and national symbol in a Post-Soviet Russia that is largely hostile to the Communist project. This brief sketch as to the evolution of the ways in which the Victory Banner has been presented in Soviet museums gives us a sense of its evolution as a key symbol for Soviet and Russian commemoration of the war. However, it is only really by considering the rituals associated with the Victory Banner that one can truly grasp its sacred power.

\section{Rituals of the Flag}

From the moment of the Victory Banner's first arrival in the Central Museum of the Red Army in 1945, it was common for members of the Pioneers, the official Soviet youth organisation, to make their promise by it (Arsenin 1953, 94). Invoking Durkheim, we might describe these as rituals of consecration that enabled the participants to partake of the Victory Banner's sacred power. Such power was even more in demand following Stalin's death and, in the wake of the 1956 decision to permit the forming of Union-wide veterans' organisation (Edele 2008, 162), Victory 
Day became a focus for their activity and veterans began to gather together in Moscow in the period between 15 April and 10 May. The Central Museum of the Armed Forces' Victory Hall became packed in this period, as thousands of people, especially participants in the storming of the Reichstag, come to pay their respects to the dead and to reminisce (Shatilov 1988, 188). The choice of the Victory Hall, dominated by the Victory Banner, was symbolic.

Emboldened by their discovery of their power to organise, veterans strove to seize greater control over the narrative of the war in general, and of the Victory Banner. The flag itself began to leave the premises of the museum to take part in their gatherings. A 1962 guidebook describes this phenomenon:

Participants in the Battle of Berlin often come to the Museum, to the Victory Banner. On numerous occasions, heroes of the Soviet Union Egorov, Kantariia, Neustroev, S'ianov and other veterans of the Great Patriotic War have spoken in the Museum about their memories of the raising of the Victory Banner. On occasion the Victory Banner, accompanied by a guard of honour, has been ceremonially displayed at meetings devoted to notable events in the history of the Soviet Army (Anon 1962, 151-52).

The use of the flag in commemorative political meetings, such as the enormous gathering in the Lenin stadium Moscow on 9 May 1960, commemorating the $15^{\text {th }}$ anniversary since the end of the war, was part of growing grassroots pressure from veterans for whom the war was the central event of their lives and of the Soviet Union's history. Seen in this light, the decision to declare Victory Day a public 
holiday, and to stage the enormous 1965 parade, the first since 1946, was not solely a myth imposed from above, a manipulation through guilt (Tumarkin 1994, 133), but also part of a bid by the state to assert control over a powerful grassroots impulse to intensify commemoration of the war (Weiner 2001). As Russian historian Boris Dubin has argued, the state mobilised every possible institutional means from parades, medals, monuments, film, literature and so forth, to ensure that it retained 'the monopoly as keeper of memory and constructor of history' as part of a 'symbolic politics' (Dubin 2008).

Although the Victory Banner does not figure in Dubin's list, it too was a crucial part of the resurgent cult of the war. Effectively the Victory Day parade controlled and regimented uses of the flag, incorporating it into a solemn state-endorsed ceremony and removing it from the unpredictable and harder to manage sphere of spontaneous political meetings. Possession of this artefact, and the power to shape its symbolic meaning, was a key part of this battle, the struggle to determine the meaning of victory in the war for Soviet society.

It is in this period of change, when the fully-fledged war cult first starts to coalesce, that the Victory Banner artefact comes to play a particularly important role. One way of understanding this is through the need for new symbols for the state in the vacuum left by the critique and collapse of the Stalin cult. As Mate Rolf argues: 'Power needs symbols and it needs to be conveyed symbolically'. This symbolic dimension is particularly important in difficult times, and times of transition due to the power of symbols to confer stability through repetition (Rolf 2013, 41). This need for symbols and repetition fuelled the creation of the various Victory Day rituals. The holy associations of the Victory Banner are particularly important here, since a mystical 
dimension is an important factor in both rituals and the most effective flags (Pastoreau 2004, 296). Thus, in the 1965 parade, the Victory Banner is almost the main star: there are many close ups of it in the newsreel footage $\left(20^{\text {th }}\right.$ Anniversary of the Great Feat (20-letie velikogo podviga), Irina Setkina and Elena Vermisheva, 1965). It is likewise referred to as a 'holy relic of war' in the voice-over commentary. The cultivation of this holy aura around the Victory Banner was not only a way of generating symbolic capital in the absence of the Stalin cult or a new leader cult, but it was also an attempt to add a sense of mystique and tradition that was distinctly lacking in 1965 in comparison to 1945, when the Soviet generals rode into Red Square on horseback: here Minister of Defence Rodion Marinovskii inspected the parade from a limousine (a pattern repeated throughout the subsequent Soviet Victory Day parades) — the motorised arrival echoed the focus on new, powerful military technologies such as rockets.

Yet the fact that the Victory Banner came to play so important a role in post-Stalin war commemoration culture is indicative of the Brezhnev era's often implicit rehabilitation of Stalin. The original banner had initially been firmly associated with Stalin, who had personally ordered a Victory Banner to be raised over Berlin, and newsreel depictions of its raising emphasised that this was the carrying out of Stalin's order; similarly, the initial post-war presentation of the Banner in the Central Museum of the Red Army suggested a close association with Stalin. This may be seen as standing in contradiction with the introduction of Victory Day as the state's accommodation with post-Stalin era independent civic initiative, with the social agency of the veterans in commemoration, apparently opening the floodgates for the chaotic flux of competing and contradictory memories through an enormous 
expansion of serious historical scholarship drawing on archives, as well as myriad first person accounts and popular historical narratives (Pyzhikov 1998, 76). Polly Jones traces some of these responses to Konstantin Simonov's 1959 novel The Living and the Dead (Jones 2013, 187-98), and describes the differences between the Stalin era and post-Stalin visions of the war:

This emphasis on the visual, the corporeal, the personally witnessed and experienced, enacted a break with the spectacular and hierarchical structure of Stalinism (Jones 2013, 189).

As a physical artefact, the Victory Banner had the capacity to bridge these different kinds of visions of the war: it was a concrete visually striking object that could be situated within a network of personal testimony in memoirs, as well as photographs and newsreel film records of it supposedly being raised and flying over the Reichstag (Barbat 2014). But at the same time its singularity and display at Moscow's Central Museum of the Armed Forces and on Red Square gave it a spectacular and hierarchical charge that was redolent of and still residually associated with the leader cult: it could be mobilised to prevent the 'war cult' becoming too horizontal and democratic. Indeed, the Khrushchev era attempt to destalinise the war had established, at two specially convened conferences attended by the participants in the storming of the Reichstag, that the raising of the flag was a process in which a large number of individuals took part, and that the elevation of Egorov and Kantaria as the sole raisers of the flag was an error connected to the 'cult of personality', that is of the Stalin cult, and needed to be reassessed in favour of a notion of 'mass heroism'. ${ }^{3}$ While this version did not make it in full to the final published edition of the History of the Great Patriotic War, such complexities were decisively banished by the 1965 Victory Day parade, and the reappearance of Egorov and Kantariia as flag bearers. Henceforth, 
access to archives was strictly controlled for fear documents might be found that would support an alternative view (Maksimenkov 2015, 381), and memoirs were tightly controlled and vetted by the author's comrades and commanders, ensuring undesired themes were edited out (Kudryashov 2010, 104-05).

During the Soviet era Victory Day full military parades on Red Square were not held every year, but only on significant round dates: 1970, 1975, 1980, 1985 and 1990. On each occasion the Victory Banner was central. The most lavish and monumental was the 1985 commemoration of the fortieth anniversary of the end of the war when the parade was conducted on a greater scale than before. However, the 1990 parade had lost much of its grandeur and pomp, and with collapse of the Soviet Union the following year, the disappearance of the state that had secured the victory also led to a questioning of the need for such parades and widespread uncertainty as to the appropriate symbols with which to commemorate Victory.

\section{The Post-Soviet Fate of the Victory Banner}

In 1986, under Mikhail Gorbachev, the Soviet public were allowed to vote on whether a monument inspired by the Victory Banner would be the appropriate symbol with which to commemorate the war at the new Victory Park war memorial complex. They rejected this project (Tumarkin 1994, 149). While the precise reasons are a matter of speculation, it seems likely that they were a product of the scepticism felt towards the

official cult of the Second World War by the Soviet population at this time, fuelled in turn by a certain anti-military tone. How and whether to commemorate the war had become a divisive and complex issue in the era of glasnost. Formerly sensitive issues 
such as the Soviet retreat in 1941, the signing of the Nazi-Soviet pact, the annexation and occupation of parts of Eastern Europe, and the murder of Polish officers at Katyn were being openly discussed to the detriment of the traditional patriotic narrative of the Soviet Union as saviour. The 1990 parade reflected this uncertainty: Tumarkin describes it as brief, small in scale and lacking in the 'swagger' of previous years as a result of the state of the crisis facing the country, and the widely held perception that its social system and ideology were not after all superior to those of the west (Tumarkin 1994, 200). Nevertheless, the Victory Banner, and the other traditional trappings of the parade, still featured.

Seeking to break with the symbolism of the Soviet Union, and emphasise a new democratic identity, under the Russian Federation's first president Boris Yeltsin, from 9 May 1992 there was a very low-key marking of Victory Day, with no parade and an emphasis on a victory being achieved despite, rather than because of Stalin and the Communist system. However, Yeltsin's Communist opponents began to gather and mobilise at the Victory Park memorial complex every 9 May to preserve the Sovietera myth and, in order not to let the fiftieth anniversary events fall into their hands, he was forced to sponsor the Victory Day events in 1995 and to permit a red flag of the Victory Banner to co-exist with the new tricolour of the Russian state (Smith 2002, 99). However, the 1995 parade occurred in two distinct parts. In the 'historical part', veterans assembled on Red Square where they were inspected by generals in limousines, and the Victory Banner was paraded, in both cases following the model established in 1965. However, while there was also a march by of troops in Second World War era uniforms bearing period submachineguns, the parade of contemporary military hardware took place at Victory Park. There was also an enormous image of a 
Soviet and an American soldier displayed on the Historical Museum facing Red Square. Together these changes symbolised a Yeltsin-era break with the narrative of the victory as exclusively Soviet and with the overtly militaristic message. Despite these changes, the fact that the parade had even taken place was effectively a recognition that Yeltsin's democrats had not succeeded in creating their own novel rituals and symbols, and were instead forced to reconcile themselves to and resurrect the rituals of commemoration invented in the Stalin and Brezhnev periods (Smith 2002, 85-91).

However, Yeltsin, who had banned the Communist Party of the Russian Soviet Federal Socialist Republic in 1991, was still anxious to control and restrict the circulation of Soviet era imagery, including that of the Victory Banner. For this reason he introduced a law in 1996 which permitted exact facsimile copies of the Victory Banner but only for official state ceremonies on Victory Day and Defender of the Motherland Day (23 February, formerly Red Army Day), and only in conjunction with the new Russian national flag. In all other cases, instead of exact copies, organisers of local parades and so on were to use the 'Symbol of the Victory Banner', which was a red flag with a five-pointed star on it, and no hammer and sickle. ${ }^{4}$ This need to restrain the use of so powerful a symbol is interesting and a further indication of the Yeltsin government's ineffective attempts to break with the Communist heritage, and failure to find a symbol with comparable resonance. The Communists (CPRF) ridiculed this as a cross between the Chinese and Vietnamese flags, and a contemptible sign of the embarrassment before the symbol of Russia's greatest historical achievement (Slivko 2014). 
Even before he was inaugurated as president on 7 May 2000, Vladimir Putin evoked the memory of the Second World War, and associated himself with Russia's victory (Wood 2011). This remembrance of the war has been a central part of the Putin project to restore national pride and project Russian power globally. The association of the war with Stalin has not concerned Putin's administration, since this association too is one they make use of. Since 2000, 9 May has become Russia's most important national holiday and day of commemoration, and since 2005 has involved a full military parade with rockets, tanks and the full pomp evident in the Soviet parades prior to 1990. In each case, the Victory Banner has been central. Then in 2007, the Communists proposed to replace the whole notion of the 'Symbol of the Victory Banner' with exact replicas of the original flag, bearing both the hammer and sickle and name of the unit. Ceding to Communist pressure and at the same time stealing their thunder, president Putin passed a law on 7 May 2007 that overturned the Yeltsin era statute, and abolished the notion of the 'Symbol of the Victory Banner'. Now, facsimile copies of the Victory Banner could be used by any organisation or any one honouring the memory of the war (Kruglov 2007). By this point the Victory Parade had become an annual fixture, with the Victory Banner at its centre, and the 'cult of the war' was once again in full swing.

\section{Re-Enactments and Demonstrations in the Post-Soviet Space}

The 2007 change in the law has fuelled a rise in the use of facsimiles of the Victory Banner, which has been paralleled by the growing popularity of military re-enactment - termed 'reconstruction' (rekonstruktsiia) in Russian - since the 1990s. As Jenny Thompson has noted, for re-enactors, genuine or replica artefacts play a key role in 
authenticating the bearer's right to own or control history (Thompson 2010, 135). In addition to replica uniforms and weapons, copies of the Victory Banner, as an artefact, have become used in public re-enactments, sometimes re-enacting the storming of the Reichstag, thus confirming their potency as a symbol authenticating the dominant Russian account of the Great Patriotic War as glorious victory.

The fact that the movement began following the collapse of the Soviet Union, in the early 1990s, when official military parades on Red Square had ceased, meant that 'reconstruction', by the virtue of employing banned Communist symbols, immediately possessed a more intense political charge than was the case in places like the United States, where the politics, if present, are implicit and not central (Thompson 2010, 125-34). Moreover, while American re-enactors rarely stage particular events, being more oriented towards recreating and reliving the experience of the common soldier, in the Russian and Ukrainian context, the restaging of particular events such as the liberation of specific towns and cities or the storming of the Reichstag are more popular scenarios.

One significant expression of this political dimension in the growth of military reenactment, and practices close to it, is the use of auratic objects of veneration normally housed in museums, or at least replicas of them, as with as the Victory Banner. Moreover, the cross over between practices of re-enactment and politics is evident most acutely in the events surrounding the tensions and armed conflict in East Ukraine. It is probably no coincidence that Igor Strelkov (aka Igor Girkin), the onetime prominent insurgent leader in East Ukraine, had long been an ardent military reenactor. 
Following the Victory Banner's 2007 reinstatement as an officially sanctioned symbol of Russian and Soviet victory in the war, the flag also became a symbol of proRussian identity in Ukraine. Following his 2010 election, Ukraine's Party of the Regions president, Viktor Ianukovich, began to actively promote it: in April 2011, in the run up to Victory Day, Ianukovich's government passed a law requiring Ukrainian national and regional governments to fly facsimiles of the Victory Banner on 9 May, and use it in remembrance ceremonies. ${ }^{6}$ The symbol had not formerly played an important role in post-Soviet Ukraine and this was a highly provocative and divisive move, which flew in the face of local authorities in the Ukrainian-speaking west of the country banning use of the red flag in all its guises. ${ }^{7}$ In Russian-speaking cities such as Khar'kov, and Odessa, however, Ianukovich's new law was enthusiastically obeyed on Victory Day 2011 with the parading of a copy of the Victory Banner, in imitation of the Moscow parade, albeit alongside the Ukrainian flag. This was preceded by dancing and a parade by reenactors in Second World War period uniforms. In Kiev itself, there was a historic parade, featuring people in uniforms and with period weapons.

As in Russia in the early 1990s, the Communists, especially in Russian-speaking regions, attempted to seize the initiative, and organised their own demonstrations with an enormous copy of the Victory Banner 2011((pseudonym) 2011). In Odessa in 2012 there was an actual reconstruction of the storming of the Reichstag, re-enacted before a festive crowd in bright sunshine on the beach, and a copy of the Victory Banner was carried into battle and raised to signify the Soviet triumph (Chernysheva 2012). The spectacle was organised by the Odessan chapter of Ianukovich's Party of the Regions. 
The following year, on 22 June 2013, a reconstruction of the battle for Kiev was followed by the hoisting of a copy of the Victory Banner by the local authorities. ${ }^{8}$ In each case, the events were photographed and filmed for subsequent dissemination on the internet.

Predictably, in the west of the country there was a hostile reaction to the revival of this Soviet-era symbol. On 9 May 2011 in L'viv, copies of the Victory Banner were publicly defiled, repeatedly driven over by a motor cavalcade, before they were burnt to the sound of the chant, 'hammer and sickle — death and famine'. 9 Since Ianukovich's 2014 toppling from power, copies of the Victory Banner have been widely used a symbol by pro-Russian demonstrators and forces in Ukraine, but are now effectively banned in, for example, Odessa. ${ }^{10}$

In Russia, the Victory Banner has in parallel become an even more important and widely disseminated symbol, especially with the state-sponsored anti-Maidan movement. So in March 2015, a giant 200 square metre copy of the Victory Banner began a 25,000 kilometre journey starting in Sevastopol, through ninety towns and cities, and ending up on Victory Day in Novorosiisk, one of the Soviet 'hero cities'. It was transported as part of a supposedly long-running 'international' project, a motor race entitled 'Our Great Victory.' The report of the Kuban regional site of the Rossiia news channel, explained the symbolism:

In the three years that the project 'Our Great Victory' has been running, thousands of hands of people from various ethnicities, generations and social groups have already touched it. The ritual symbolised the unity of the peoples 
who fought the German-Fascist invaders in the years of the Great Patriotic War for the freedom of our multi-ethnic Motherland. ${ }^{11}$

The emphasis here on the international dimension of war memory is significant. The Victory Banner is not just a symbol with resonance in the Russian Federation, as we have seen with regard to Ukraine: rather it symbolises precisely the international claims of Russian nationalism, and the pretensions of Russia to exert influence beyond its borders, especially in the former countries of the Soviet Union (the race also passed through Belorussia and Kazakhstan), and especially, but not exclusively, among Russian-speaking populations. At the same time, this campaign was a way of underlining that Crimea is part of Russia, as is implied by the fact that the flag began its journey in Sevastopol, on the anniversary of Crimea's unification with Russia, and was evidently intended to link that event with victory in the Great Patriotic War and the symbolism of the 9 May Victory Day parade.

\section{Conclusion}

In the years since 1945, the Victory Banner has been repeatedly recuperated for symbolic usage, to bolster the Soviet and Russian narratives of the war as a triumphant enterprise and as an achievement that inspires national pride and attachment to the Russian state. It came to the fore most of all at the beginning of the Brezhnev era, and under Putin's and Dmitrii Medvedev's presidencies: in both cases periods of retrenchment in which collective memory of the war was relentlessly mobilised as a stabilising and unifying force. The notion of the flag as sacred was built up and widely disseminated in each case. Somewhat paradoxically, in order to achieve this, since the 1960s it was widely represented and reproduced in film and 
photographs, and more recently, since 2007, through commercially available exact copies. The Banner thus has escaped from its fixed position in the Central Museum of the Armed Forces to appear on the streets, brandished by crowds of demonstrators in parades around Russian and Ukraine, and reviled and desecrated whenever possible by Ukrainian nationalists. The fact that the object of reverence and revulsion, in each case, is a copy of the flag, albeit an exact copy, rather than the original auratic object is curious: its power as an object is sustained even through the many copies.

The purpose of all this is evidently to galvanise group identity, which we might also understand in Durkheimian terms as the sanctifying of a whole group who have contact with the totemic, sacred object, and the rituals associated with it. This functions at the same time to underscore the increasingly widespread notion that the Great Patriotic War was sanctified as a holy and just war, and therefore not subject to discussion or debate. We may see this as a Putin government-orchestrated bid to endow memory of the war with a sacred aura so as to legitimise the political order in the post-Communist period, in contrast to Yeltsin's failures to articulate a new mythology of the state.

Yet seeing the exploitation of this symbol entirely in terms of government manipulation is to overlook the palpable power of the Victory Banner as an artefact, one that has genuine resonance to people, and does not depend solely on state sponsorship. As an object that can be experienced directly, or apparently so in a replica, it has been part of grassroots insurgencies for commemoration of the war in the 1960 s, the 1990 s, and more recently. Its power is such that by attending a parade where a copy of the banner is carried, by bearing it or waving it themselves, someone 
overcomes the distance that characterises history as represented by remote museums, and feels its direct presence, feels control over it. It is in this sense that we can understand the influence of and analogy to re-enactments, to living history. This is perhaps the true danger of such a mobilisation of so potent a sign — it suggests the immanence of the past, the palpability of the wartime experience, potentially enhancing its allure.

This might be contrasted to the epistemological uncertainty about the war that emerged in the late Soviet and early post-Soviet years, where eyewitnesses, including those who had raised the Victory Banner over the Reichstag (Neustroev 1990), came forward to contest accepted accounts of all manner of official versions of history, and where the photographic record of events such as the raising of the Victory Banner was subjected to criticism and critique. The incontrovertible physicality of the artefact of the Victory Banner was attractive for its literal solidity. In this regard, the Victory Banner shares its 'tactile and visual specificity' with the widely adopted black on gold George ribbon, worn on 9 May (Oushakine 2013, 291). This materiality facilitates a more personal, affective, connection with historical memory than any narrative might.

But for all its grassroots resonance, what distinguishes the Victory Banner from the Soviet flag is the fact that it bears the name of the unit who raised it written in Cyrillic. This insists on its Russianness, its unique resonance in a Russian-speaking space, and on its association with Soviet martial glory and military feats of arms. The rituals the flag is displayed in further cement this sense that this is not an internationalist, but a specifically Russian symbol. With its recent use in the anti- 
Maidan activities, it has become a nationalist symbol, the very opposite of a symbol of world revolution and of socialism.

Since the medieval world, flags have very rarely been changed, because those with mythical origins function best. To change a flag is to mark a profound break, it is a very strong symbolic act, and is rarely done (Pastoreau 2004, 291). The Yeltsin government's attempt to get rid of this symbol was symptomatic of their desire to create and signal a break with the past but, as with the attempts to ditch the Soviet national anthem, the fact that ultimately this failed is indicative of a wider difficulty in moving on, in symbolic terms, but not only in symbolic terms, from the Soviet era.

The Victory Banner delivers on its promise of continuity, and resolutely stands for and evokes Soviet victory in the Second World War as an exclusively Soviet achievement, focusing attention on the moment of triumph, on victory, and distracting gazes and thoughts from the price paid and less glorious moments. The version of history this narrative entails may be simplistic, and the Victory Banner and the whole commemoration of it may seem ridiculous to rationally minded outsiders, but the strange power it exerts is incontrovertible and enduring. Pointing out that it is part of an invented tradition will do nothing to diminish its force.

\section{References}

(pseudonym), Vladimir Ul'ianov. 2011. "Aktsiia kommunistov 'Znamia Pobedy'." https://www.youtube.com/watch?v=N7cAAJKRj_o.

Anon. 1946. Tsentral'nyi muzei Krasnoi Armii. Kratkii putevoditel'po zalam ekspozitsii. V pomoshch posetiteliu. Moscow: Izdanie Tsentral'nogo Muzeia Krasnoi Armii.

Anon. 1955. Tsentral'nyi muzei sovetskoi armii. Kratkii putevoditel'. Moscow: Voennoe izdatel'stvo Ministerstva Oborony Soiuza SSR. 
Anon. 1962. Relikvii boevoi slavy. Moscow: Voennoe izdatel'stvo Ministerstva oborony SSSR.

Anon. 1965. Tsentral'nyi muzei vooruzhennykh sil SSSR. Putevoditel'. Moscow: Voennoe izdatel'stvo Ministerstva oborony SSSR.

Anon. 1985. Zal Pobedy. Moscow: Planeta.

Anon. 2011. "Dmitrii Medvedev otkryl zal "Znamia Pobedy" v Tsentral'nom muzee Vooruzhennykh sil." Rossiiskaia gazeta, 08.05.2011. https://rg.ru/2011/05/08/znamya-anons.html.

Anon. 2015. "Tsentral'nyi muzei Vooruzhennykh sil: Ofitsial'nyi sait. Zal 18, Zal Pobedy." Accessed 10/11/15. http://cmaf.ru/ekspo/inside/129.

Arsenin, A. 1953. Tsentral'nyi muzei Sovetskoi Armii. Moscow: Moskovskii rabochii.

Assmann, Aleida. 2008. "Transformations Between History and Memory." Social Research 75 (1):49-72.

Barbat, Victor. 2014. "Bannières et drapeaux, sur quelques manières de les lever et de les représenter: I'exemple du Reichstag, mai 1945." 1895 (74):70-95.

Belting, Hans. 1998. The Invisible Masterpiece. Translated by Helen Atkins. London: Farringdon.

Benjamin, Walter. 1992. "The Work of Art in the Age of Mechanical Reproduction." In Illumination, edited by and intro by Hannah Arendt, 211-44. London: Fontana. Original edition, 1936.

Chernysheva, Elena. 2012. "Voennaia rekonstruktsiia vziatie Berlina." Odessit.ua. Accessed 12/11/15. http://www.odessit.ua/photo/389-voennayarekonstrukciya-vzyatie-reyhstaga.html.

Drozdovskii, E.A., N. K. Zakharov, M. D. Ionov, I. I. Skok, lu. G. Tiulin, N. A. Chokhonelidze, and N. A lakimanskii. 2000. Tverichi na Parade Pobedy. Tver': Litera-M.

Dubin, Boris. 2008. "Pamiat', voina, pamiat' o voine. Konstruirovanie proshlogo v sotsial'noi praktike poslednikh desiatiletii." Otechestvennye zapiski 4 (43).

Durkheim, Emile. 1995. The Elementary Forms of Religious Life. Translated by and introduction by Karen E. Fields. New York: Free Press.

Edele, Mark. 2008. Soviet Veterans of the Second World War: A Popular Movement in an Authoritarian Society 1941-1991. Oxford: Oxford University Press.

Hobsbawm, Eric. 1983. "Introduction: Inventing Traditions." In The Invention of Tradition, edited by Eric Hobsbawm and Terence Ranger, 1-14. Cambridge: Cambridge University Press.

Jones, Polly. 2013. Myth, Memory, Trauma: Rethinking the Stalinist Past in the Soviet Union, 1953-70. New Haven, CO: Yale University Press.

Kruglov, Sergei. 2007. "Istoriiu ne perepishesh'." Voenno-promyshlennyi kur'er, 9 May. http://vpk-news.ru/articles/3637.

Kudryashov, Sergei. 2010. "Remembering and Researching the War: The Soviet and Russian Experience." In Exprience and Memory: The Second World War in Europe, edited by Jörg Echternkamp and Stefan Martens, 86-115. New York \& Oxford: Berghahn.

Maksimenkov, Leonid. 2015. "Arkhivno-istoricheskoe obespechenie nyneshnego i buduiushchikh iubileev." In Pobeda-70: rekonstruktsiia iubileia, edited by Genadii Bordiugov. Moscow: AIRO-XXI.

Neustroev, Stepan. 1990. "O reikhstage na sklone let." Oktiabr' 5. 
Oushakine, Serguei. 2013. "Remembering in Public: On the Affective Management of History." Ab Imperio (1):269-302.

Pastoreau, Michel. 2004. Une Histoire symbolique du Moyen Âge occidental. Paris: Seuil.

Pisareva, I A, and F. N Poplyko. 1969. Tsentral'nyi muzei vooruzhennykh sil SSSR. Moscow: Voennoe izdatel'stvo Ministerstva oborony SSSR.

Pospelov, P. N., V. A. Andreev, A. I. Antonov, I. Kh. Bagramian, P. A. Belov, E. A. Boltin, M. G. Bragin, A.A. Grechko, I. D. Eliseev, A. A. Epishev, A. S. Zheltov, P. A. Zhilin, E. M/ Zhukov, N. A. Zhuravlev, M. V. Zakharov, I. N. Zemskov, L. F. II'ichev, D. M. Kukin, V. V. Kurasov, A. P. Kuchkin, I. I. Mints, V. P. Moskovskii, G. D. Obichkin, Z.S. Osipov, B. N. Polevoi, S. I. Rudenko, A. L. Sidorov, V. D. Sokolovskii, B. S. Tel'pukhovskii, A. A. Timofeevskii, and V. M. Khvostov. 1963. Istoriia Velikoi Otechestvennoi voiny Sovetskogo Soiuza 1941-1945. 6 (1960$1965)$ vols. Vol. 5. Moscow: Voennoe izdatel'stvo ministerstva oborony SSSR.

Pyzhikov, Aleksandr. 1998. Opyt modernizatsii sovetskogo obshchestva v 1953-1964 godakh. Obshchestvenno-politicheskii aspekt. Moscow: Gamma.

Rolf, Malte. 2013. Soviet Mass Festivals, 1917-1991. Translated by Cynthia Klohr. Pittsburgh: University of Pittsburgh Press. Original edition, 2006.

Schleifman, Nurit. 2001. "Moscow's Victory Park: A Monumental Change." History and Memory 13 (2):5-34.

Shatilov, Vasilii. 1988. $V$ boiakh rozhdennoe Znamia. 2 nd edn rev. and expanded ed. Moscow: Sovetskaia Rossiia.

Slivko, Stanislav. 2014. "Kommunisty vernuli Khabarovskomu kraiu Znamia Pobedy." Accessed 28.07.16. https://kprf.ru/party-live/regnews/127563.html.

Smith, Kathleen E. 2002. Mythmaking in the New Russia: Politics and Memory During the Yeltsin Era. Ithaca

London: Cornell University Press.

Stead, Naomi. 2007. "Performing Objecthood; Museums, architecture and the play of artefactuality." Performance Research: A Journal of the Performing Arts 12 (4):37-46. doi: DOI:10.1080/13528160701822619.

Svoichakov, Maksim. 1973. Oni brali reikhstag. Moscow: Voennoe izdatel'stvo

Synthart. 2011. "Eshche o pamiatnike Pobedy na Poklonnoi gore." Accessed 11/11/15. http://synthart.livejournal.com/217953.html.

Thompson, Jenny. 2010. War Games: Inside the World of Twentieth-century War Reenactors. Washington D.C.: Smithsonian Institute. Original edition, 2004.

Tiurin, lurii. 2000. Dva Parada. Moscow: Fond Andreia Pervozvannogo.

Tumarkin, Nina. 1994. The Living and the Dead: the Rise and Fall of the Cult of World War II in Russia. New York, N.Y.: Basic Books.

Tumarkin, Nina. 2002. "The Great Patriotic War as Myth and Memory." European Review 11 (4):595-611

Walsh, Kevin. 1992. The Representation of the Past: Museums and Heritage in the Post-Modern World. London and New York: Routledge.

Weiner, Amir. 2001. Making Sense of War: The Second World War and the Fate of the Bolshevik Revolution. Princeton, N.J.: Princeton University Press.

Wood, Elizabeth A. 2011. "Performing Memory: Vladimir Putin and the Celebration of WWII in Russia " The Soviet and Post-Soviet Review 38:172200. 
Notes

All translations from Russian are my own.

${ }^{1}$ The $150^{\text {th }}$ Idritskaia Division, order of Kutuzov $2^{\text {nd }}$ class, 79th Rifle Corps, 3rd Strike Army, 1st Belorussian Front ('150 стр. ордена Кутузова II ст. идрицк. див. 79 С.К. 3 У. А. 1 Б. Ф.'). There is a number ' 5 ' on the reverse side, indicating that it was the fifth of the nine banners issued to combat divisions before the storm of the Reichstag.

${ }^{2}$ Although Tumarkin realizes this miscalculation in a later revision of her thesis written at the beginning of the Putin era: (Tumarkin 2002).

${ }^{3}$ Stenogramma soveshchaniia otdela istorii velikoi otechestvennoi voiny na temu 'Shturm Reikhstaga'. In Institut Marksizma-Leninizma pri TsK KPSS, otdel istorii velikoi otechestvennoi voiny, November 1961, RGASPI (Russian State Archive of Social and Political History) 71/22/102.

4 "Ukaz Prezidenta Rossiiskoi Federatsii ot 15 aprelia 1996 'O znameni Pobedy' N. 561 (Decree of the President of the Russian Federation 15 April 1996, 'On the Victory Banner')." 15 April 1996 http://sbornik-zakonov.ru/215419.html. Accessed 12/11/15.

5 "Federal'nyi zakon Rossiiskoi Federatsii ot 7 maia 2007g. N 68-F3 "O Znameni Pobedy"' (Federal Law of 7 May 2007 N 68-F3 'On The Victory Banner"')." Rossiiskaia gazeta, 8 May 2007. http://www.rg.ru/2007/05/08/znamya.html. 6 "Rada obiazala podnimat' krasnoe znamia v Den' Pobedy." Zerkalo nedeli, 21 April 2011. Accessed 12/11/15. 
http://zn.ua/SOCIETY/rada_obyazala_podnimat_krasnoe_znamya_v_den_pobedy .html. (Accessed 01.08.16).

7 "Rada obiazala podnimat' krasnoe znamia v Den' Pobedy." Zerkalo nedeli, 21 April 2011.

http://zn.ua/SOCIETY/rada_obyazala_podnimat_krasnoe_znamya_v_den_pobedy .html. (Accessed 01.08.16)

${ }^{8}$ http://krasna-vest.narod.ru/fakt/dot179_rek.html. 2013. (Accessed 01.08.16)

${ }^{9}$ https://www.youtube.com/watch?v=8ERXH1LYx2c. 2011. (Accessed 01.08.16) 10 "V Odesse zapretili znamia Pobedy." lenta.ru, 23/10/15. Accessed 12/11/15. http://lenta.ru/news/2015/10/23/flag/. 11 "B Novorosiisk privezut 200-metrovoe Znamia Pobedy." 2015. Accessed 25.03.15. http://kubantv.ru/pobeda/91809-gigantskoe-znamia-pobedyprovezut-po-gorodam-kubani/?utm_source=dlvr.it\&utm_medium=twitter 